\title{
Rancang Bangun Sistem Informasi Seleksi Proposal P3M
}

\author{
Zulkarnaen Hatala ${ }^{1}$ \\ ${ }^{1}$ Politeknik Negeri Ambon \\ Jl. Ir. Putuhena Wailela Rumah Tiga Ambon, 97234 , Indonesia
}

\begin{abstract}
Proposals selection process for Research and Community Service in Politeknik Negeri Ambon still performed manually. Individual sub processes separated, not integrated causing inefficiency. Sistem Informasi Seleksi Proposal P3M (SIMLITABNAM) comes to solve problems found. Integrated system take advantage of Information technology, will offer efficiency and accuracy. Online System provides more flexibility for researchers, reviewers and other stakeholders. The system developed guided by proven Software Engineering methods, guarantees quality and easiness of maintenance. Obviously his application benefit to every person involved in the process.
\end{abstract}

Abstrak-Pengelolaan seleksi Proposal Penelitian Dan Pengabdian Masyarakat pada Politeknik Negeri Ambon masih dilakukan secara konvensional. Proses-proses dalam penyeleksian dilakukan secara terpisah, memakan waktu yang lama dan menyulitkan dalam proses koordinasi. Selain itu proses tersebut belum bisa dilaksanakan secara daring(online). Sistem informasi seleksi proposal merupakan sebuah aplikasi yang mampu mewadahi kebutuhan yang disebutkan di atas. Aplikasi ini sekarang dikembangkan berbasis web secara daring. Metoda pengembangan perangkat lunak yang digunakan adalah waterfall with increment. Aplikasi ini bisa memberikan layanan yang lebih baik dan akses lebih luas kepada pihak-pihak yang terkait dalam proses Seleksi proposal Penelitan dan Pengabdian Masyarakat pada Politeknik Negeri Ambon.

Keywords - sistem informasi manajemen, seleksi proposal.

\section{Pendahuluan}

\section{A. Latar Belakang}

Pusat Penelitian dan Pengabdian Kepada Masyarakat mempunyai beban kerja bagi staf di lingkungan Pusat Penelitian Dan Pengabdian Masyarakat(P3M). Mengingat peran dan fungsi dari lembaga ini yaitu sebagai salah satu unsur di Politeknik Negeri Ambon (POLNAM) yang berfungsi untuk mengkoordinasikan, memantau dan menilai pelaksanaan dan kegiatan penelitian yang diselenggarakan oleh pusat-pusat penelitian atau pun oleh kelompok-kelompok peneliti dari berbagai fakultas dan program studi. Selain itu, P3M juga berperan untuk memberikan pelayanan bagi para peneliti di lingkungan POLNAM dalam hal penyediaan informasi penelitian, proses administrasi dan juga layanan pembinaan kemampuan para peneliti.

Gairah penelitian yang dilaksanakan oleh para peneliti di lingkungan POLNAM menunjukkan perkembangan yang sangat baik. Hal ini ditunjukkan oleh peningkatan jumlah proposal yang dikelola oleh P3M dari tahun ke tahun. Seperti contohnya jumlah proposal penelitian yang diterima oleh P3M untuk dikompetisikan pada semua hibah yang dikelola oleh P3M hingga 2018. Data ini menunjukkkan peningkatan jumlah proposal yang dikelola P3M sangat signifikan. Dengan peningkatan kualitas SDM POLNAM dan juga melalui pembinaan yang semakin baik dan ditunjang dengan pengelolaan yang semakin transparan dan akuntabel, gairah penelitian di POLNAM akan berkembang semakin baik. Sistem Informasi Pengelolaan Proposal Penelitian secara online akan memberikan kemudahan baik bagi peneliti, reviewer dan juga bagi pengelola yaitu P3M. Jarak antar kampus yang cukup jauh dan juga keterbatasan jam kerja di kantor P3M yang efektifnya dari jam 08.00 - 16.30 Witimur untuk 5 hari kerja, akan teratasi dengan sistem registrasi online. Dengan cara ini, peneliti bisa meregistrasikan proposalnya dari mana saja dan dalam waktu 24 jam dalam sehari. Kemudahan juga diberikan kepada reviewer karena mereka dapat memberikan penilaian setiap saat dan dari mana saja.

\section{B. Permasalahan}

Banyak permasalahan dan tantangan yang dihadapi dalam proses administrasi seleksi Proposal Penelitian dan Pengabdian Masyarakat. Para pihak yang terlibat dalam proses seleksi proposal Penelitian Dan Pengabdian memiliki keluhankeluhan yang sebisanya bisa dicarikan solusi atas permasalahannya.

Pada seleksi proposal para peneliti menghadapi masalah keterbatasan waktu dan tempat jika ingin mengumpulkan proposal penelitiannya. Kadangkadang peneliti dosen sedang berada di luar kota pada saat tenggat waktu berakhir. Dengan sistem seleksi online maka hal ini bisa di atasi, hal yang sama dialami oleh tim penilai/reviewer dalam menjalankan proses penilaian (reviewing).

Masalah lainnya muncul mengenai isi dan kualitas proposal. Para peneliti dan tim penilai membutuhkan referensi dari proposal sebelumnya 
sehingga bisa menghindari kasus duplikasi, plagiasi dan pengulangan yang bisa menyebabkan turunnya mutu proposal, bahkan bisa berakibat ditolaknya proposal penelitian dan pengabdian tersebut.

\section{Ruang Lingkup}

Simlitabnam yang dikembangkan pada tahap ini tidak menyediakan fungsi monitoring dan evaluasi secara umum, hanya proses pendaftaran dan penilaian (reviewing).

\section{Tinjauan Pustaka}

Sistem Informasi Strategis

Sistem Informasi dengan tujuan memperoleh keunggulan bersaing digolongkan sebagai Sistem Informasi Strategis [1].

\section{Unified Modeling Language}

Dalam proses pengembangan Sistem Informasi dengan metoda Waterfall [2], pemodelan dengan Unified Modeling Language (UML) [3] dilakukan pada tahap analisa. Hasil dari analisa menggunakan UML adalah dokumen-dokumen yang disebut artifak [3]

LAN dan Internet

Jaringan komputer didefinisikan rekursif adalah dua atau lebih node (komputer) yang terhubung oleh physical link atau oleh jaringan jaringan yang dihubungkan oleh sebuah node. Local area network (LAN) mempunyai cakupan kurang dari $1 \mathrm{~km}$ [4]. Internet adalah sistem global antar jaringan komputer global atau Internasional yang menggunakan protokol TCP/IP untuk menghubungkan setiap perangkat dalam skala Internasional.

\section{Tujuan dan Manfaat}

\section{Ruang Lingkup}

Tujuan dari penelitian ini adalah menghasilkan Sistem Informasi Seleksi Proposal Penelitian dan Pengabdian Masyarakat (SIMLITABNAM) berbasis daring/online, untuk Pusat Penelitian Dan Pengabdian Masyarakat Politeknik Negeri Ambon (P3M).

\section{E. Manfaat}

Manfaat yang diperoleh dari kegiatan penelitian ini antara lain :

- Meningkatkan efektifitas dan efisiensi kinerja dosen dalam melakukan tupoksi berkaitan dengan P3M.

- Meningkatkan efektifitas dan efisiensi kinerja pihak manajemen dan administrasi pada P3M Politeknik Negeri Ambon.
- Meningkatkan efektifitas dan efisiensi kinerja tim reviewer pada P3M Politeknik Negeri Ambon.

- Meningkatkan kualitas proposal pada P3M pada Politeknik Negeri Ambon.

\section{Metoda Penelitian}

\section{F. Software engineering process}

Metodologi penelitian yang digunakan adalah metoda pengembangan perangkat lunak (software engineering process) waterfall with increment [2]. Metoda top-down/waterfall berulang dengan perbaikan di sebut juga incremental model, dan diilustrasikan pada gambar 1 .

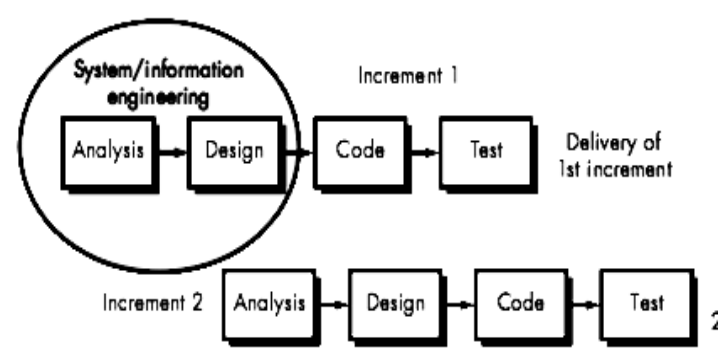

Gambar 1. Incremental model

Incremental model jika diterapkan pada studi kasus Simlitabnam maka diilustrasikan sebagai berikut:

1) Pengumpulan Kebutuhan dan analisis data (Requirement Collection and Analysis). Pada fase ini dikumpulkan semua fungsional sistem. Biasanya dijabarkan dalam artifak use case diagram. Sebagai contoh tahap pertama adalah menentukan pengguna sistem (actors). Di sistem ini kita sepakati bahwa user sistem kita adalah administrator, pengusul dan reviewer, sebagaimana digambarkan pada gambar 2 .

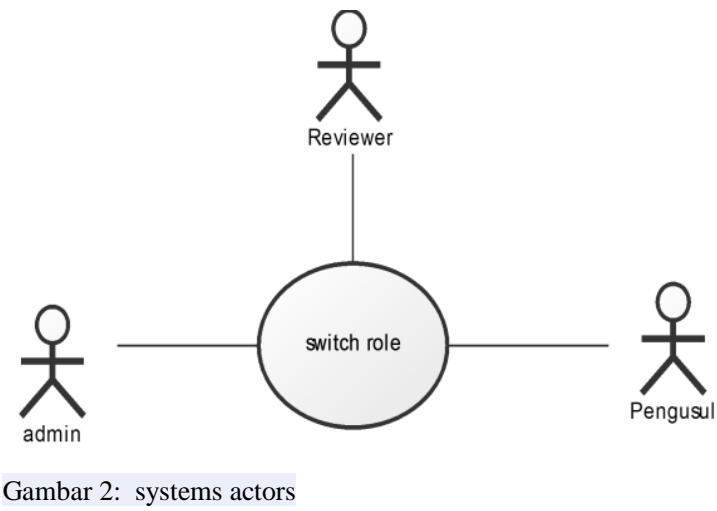

2) Perancangan (Design) 
- Perancangan basis data konseptual (Conceptual Database Design) Pada tahapan ini biasanya model dasar basis data untuk penyimpanan informasi di buat dalam bentuk Entitiy Relationship Diagram (ERD) [5]. Sebagai contoh, sebagian ERD dari Simlitabnam adalah pada Gambar 3 berikut.

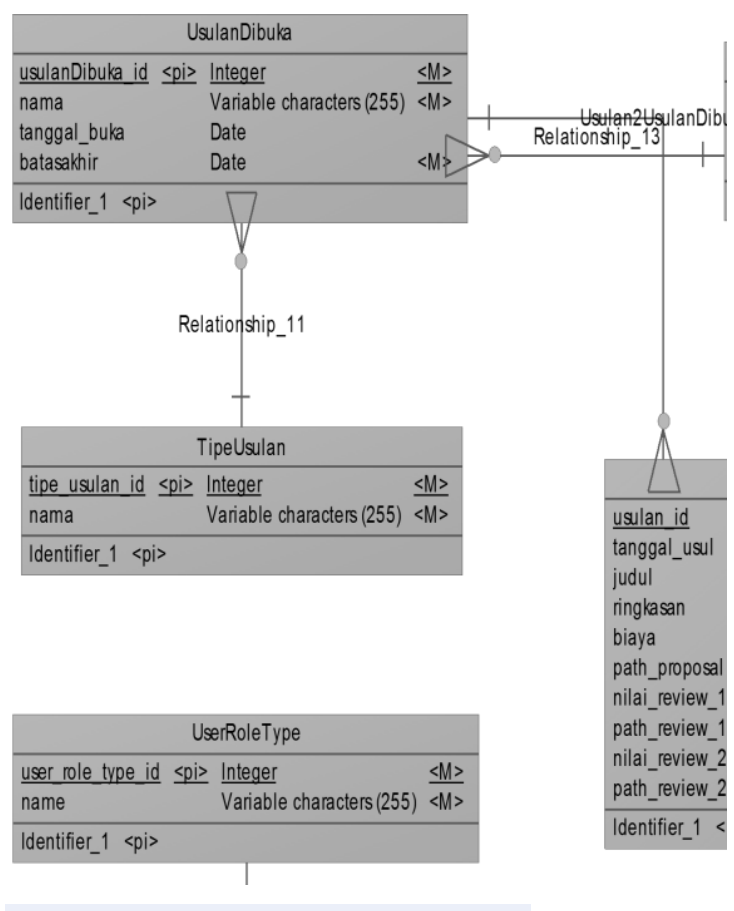

Gambar 3: Entity Relationship Diagram (ERD)

- Perancangan Antar Muka (User Interface), perancangan antar muka aplikasi terkait erat dengan Business Process dalam organisasi tersebut. Contoh desain antar muka bisa dilihat pada poin g) di bawah.

3) Implementasi Pemograman dan Instalasi, pada fase ini pemograman dan instalasi hardware dilakukan. Tahapannya adalah ;

- Instalasi Hardware dan jaringan atau verifikasi system existing

- Instalasi Operating System

- Instalasi dan Admistrasi Web

- Penulisan Program

4) Testing, uji coba, uji coba dilakukan terhadap data yang ada. Jika dalam uji coba di rasa belum layak maka semua proses diarahkan ke langkah (1) analisa tetapi masuk tahap/fase/incremental berikutnya. Demikian dilakukan berulang-ulang hingga dirasa layak dan memadai maka software akan dirilis.

5) Pelepasan (Launching And Releasing), Sistem Informasi di-launching-setelah dipasang di internet dengan cara hosting dan co-location. Dengan demikian seleksi proposal P3M bisa dilaksankan secara online. Sistem Informasi di-release dengan cara source code-nya diletakkan di internet agar bisa diakses secara bebas dan gratis (freedom and free lunch) untuk digunakan oleh unit P3M kampuskampus lainnya.

\section{Hasil \\ G. Proses Bisnis dan Antar Muka Grafis}

Fungsionalitas atau use case untuk semua actor akan terlihat sepintas dalam formulir aplikasinya. Misalnya terlihat 3 aktor yang terlibat yaitu Administrator, reviewer dan pengusul P3M menggunakan use case/fungsionalitas login. Maka tampilan antar muka yang mewakili adalah seperti pada gambar 4:

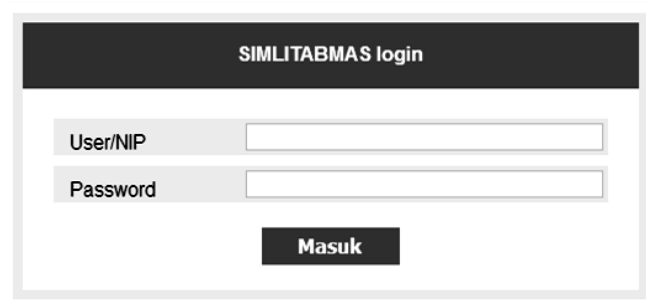

Gambar 4: user interface untuk use case login

Pada form login di atas untuk memproteksi akses yang tidak diinginkan. Tampilan awal (DashBoard) adalah tampilan setelah user selesai login, seperti dilihat pada gambar 5 .

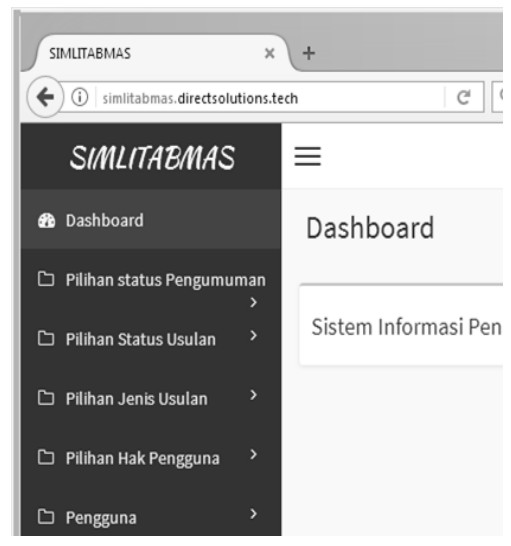

Gambar 5: Tampilan Dashboard

\section{Kesimpulan dan Saran}

\section{H. Kesimpulan}

Simlitabnam[6]berhasil dikembangkan dengan metoda Software Engineering Process Waterfal 
(with) incremental. Simlitabnam dirancang beroperasi online berbasis web sehingga semua business process bisa dilaksanakan secara online. Dengan demikian mempunyai nilai tambah karena subproses masih bisa dilaksanakan tanpa halangan waktu dan tempat.

\section{Saran}

Karena Simlitabnam dikembangkan berbasis jaringan web dan multi user maka sebaiknya Simlitabnam diperbaiki, dipelihara dan diperbarui secara berkala, terutama berkenaan masalah keamanan dan integritas data. Simlitabnam masih kekurangan beberapa fitur yang bisa dikembangkan pada tahap berikutnya:

- Use case untuk fungsi Monitoring dan evaluasi (MONEV)

- Peningkatan keamanan(security issues)

- Perbaikan tampilan/Web User Interface

- Kajian performansi, aksesibilitas dan kompatibilitas browser (WWW/Internet)

\section{Referensi}

[1] M. Hemmatfar and D. Ph, "Competitive Advantages and Strategic Information Systems," Int. J. Bus. Manag., vol. 5, no. 7, pp. 158-169, 2010.

[2] R. Pressman and B. Maxim, Software Engineering: A Practitioner's Approach, 8th ed. McGraw-Hill, 2014.

[3] G. Booch, J. Rumbaugh, and I. Jacobson, The Unified Modeling Language Reference Manual, 2nd ed. Addison Wesley, 2004.

[4] L. L. Petterson and B. S. Davie, Computer Network: A Systems Approach, 5th ed. Elsevier, 2011.

[5] I. Song, M. Evans, and E. K. Park, "A Comparative Analysis of Entity-Relationship Diagrams," J. Comput. Softw. Eng., vol. 3, no. 4, pp. 427-459, 1995.

[6] Z. Hatala, "(2018) Open Source Proposals Selection System For University Research And Community Service Founding," $2018 . \quad$ [Online]. Available: https://github.com/dzhatala/simlitabmaspolnam. [Accessed: 07-Oct-2018]. 